\title{
Toxoplasmosis in Three Species of Native and Introduced Hawaiian Birds
}

\author{
Author(s): Thierry M. Work , J. Gregory Massey , David S. Lindsay , and J. P. Dubey \\ Source: Journal of Parasitology, 88(5):1040-1042. 2002. \\ Published By: American Society of Parasitologists \\ DOI: http://dx.doi.org/10.1645/0022-3395(2002)088[1040:TITSON]2.0.CO;2 \\ URL: http://www.bioone.org/doi/full/10.1645/0022-3395\%282002\%29088\%5B1040\%3ATITSON \\ $\% 5 \mathrm{D} 2.0 . \mathrm{CO} \% 3 \mathrm{~B} 2$
}

BioOne (www.bioone.org) is a nonprofit, online aggregation of core research in the biological, ecological, and environmental sciences. BioOne provides a sustainable online platform for over 170 journals and books published by nonprofit societies, associations, museums, institutions, and presses.

Your use of this PDF, the BioOne Web site, and all posted and associated content indicates your acceptance of BioOne's Terms of Use, available at www.bioone.org/page/terms_of_use.

Usage of BioOne content is strictly limited to personal, educational, and non-commercial use. Commercial inquiries or rights and permissions requests should be directed to the individual publisher as copyright holder. 
American Society of Parasitology. Thierry M. Work, J. Gregory Massey, David S. Lindsay, and J. P. Dubey (2002). "Toxoplasmosis in Three Species of Native and Introduced Hawaiian Birds," Journal of Parasitology, Vol. 88, No. 5, pp. 1040-1042. doi: http:// dx.doi.org/10.1645/0022-3395(2002)088[1040:TITSON]2.0.CO;2

\section{Toxoplasmosis in Three Species of Native and Introduced Hawaiian Birds}

Thierry M. Work, J. Gregory Massey*, David S. Lindsaył, and J. P. Dubeył, Hawaii Field Station, National Wildlife Health Center, U.S. Geological Survey, P.O. Box 50167, Honolulu, Hawaii 96850; *Hawaii Department of Land and Natural Resources, 2600 Piiholo Road, Makawao, Hawaii 96795; †Virginia Tech, 1410 Prices Fork Road, Blacksburg, Virginia 24061-0342; ‡ Epidemiology and Systematics Laboratory, Parasite Biology, Animal Resources Institute, Agricultural Research Service, U.S. Department of Agriculture, Building 1001, BARC-East, Beltsville, Maryland 20507-2350. e-mail: thierry_work@usgs.gov

ABSTRACT: Toxoplasma gondii was found in endemic Hawaiian birds, including 2 nene geese (Nesochen sandvicensis), 1 red-footed booby (Sula sula), and an introduced bird, the Erckels francolin (Francolinus erckelii). All 4 birds died of disseminated toxoplasmosis; the parasite was found in sections of many organs, and the diagnosis was confirmed by immunohistochemical staining with anti-T. gondii-specific polyclonal antibodies. This is the first report of toxoplasmosis in these species of birds.

Toxoplasma gondii can cause mortality and subclinical infections in many species of warm-blooded animals including birds (Dubey and Beattie, 1988; Literák et al., 1992; Dubey, 2002). In tropical island ecosystems, $T$. gondii has been documented only on islands with feral cats, underlining the fact that felids are the only known definitive hosts (Wallace et al., 1972). In Hawaii, T. gondii has significantly affected reintroduction programs for the endangered Hawaiian crow (Work et al., 2000). This article documents acute toxoplasmosis in 3 other species of endemic and introduced Hawaiian birds, including nene goose ( $\mathrm{Ne}$ sochen sandvicensis), the red-footed booby (Sula sula), and Erckels francolin (Francolinus erckelii).

Birds were submitted refrigerated within $12-24 \mathrm{hr}$ of death to the Hawaii Field Station or the Hawaii Department of Fish and Wildlife. Birds were weighed and examined systematically externally and internally. Tissues including brain, heart, lung, skeletal muscle, kidney, spleen, adrenal, small and large intestines, trachea, and liver were fixed in $10 \%$ buffered formalin, sectioned at $5 \mu \mathrm{m}$, and stained with hematoxylin and eosin for microscopic examination. Immunohistochemistry was done on paraffin-embedded sections using polyclonal anti- $T$. gondii and anti-Sarcocystis neurona antibodies and anti-BAG-1 antibodies specific for bradyzoites (Lindsay and Dubey, 1989; McAllister et al., 1996; Dubey and Hamir, 2000).

Two endangered Hawaiian goose (nene) goslings housed in a sand enclosure were found dead 3 days apart in August 1994 at a private zoo on Maui. Gross examination revealed both birds ( 1 male, 1 female) to be in excellent body condition with adequate fat reserves. The only significant gross lesion in the female included focal congestion of the liver, marked splenomegaly, heavy wet lungs, and locally extensive fibrinous exudates on the jejunal mucosa. The main gross lesions in the male included marked hemorrhage and consolidation of the left lung, marked splenomegaly, and linear brown areas of discoloration on the large intestinal mucosa.

Histology in the female gosling revealed severe interstitial mononuclear pneumonia with intracytoplasmic tachyzoites, focal lytic hepatic necrosis, focal neuronal necrosis, severe lymphoid depletion, and severe, diffuse, nonsuppurate inflammation and necrosis of the myocardium and skeletal muscles associated with tachyzoites. There also was full-thickness necrosis of the intestinal wall extending through the lamina propria and muscularis associated with marked mononuclear response and tachyzoites. Significant microscopic findings in the male gosling included focal necrosis and marked mononuclear interstitial infiltrates associated with tachyzoites in the lung, mild focal necrosis and nonsuppurative inflammation associated with myocardial necrosis, severe lymphoid depletion, and tachyzoites in the spleen and tissue cysts with bradyzoites in the adrenal. Tissue cysts positive for BAG-1 were seen in the brain, lung, and heart (Fig. 1A-C). The brain was not examined.

In February 1995, a free-ranging Erckel's francolin was found dead on Kauai. This was a female adult in excellent body condition. Significant gross lesions included focal discoloration of the liver and heart, heavy wet mottled lungs, and a crop distended with ingesta. Histology revealed mild focal acute hepatocellular necrosis, severe myocardial necrosis and mononuclear inflammation, mild focal cerebral gliosis, and severe diffuse splenic necrosis associated with tachyzoites (Fig. 1D).

The fourth case was a red-footed booby adult that was found weak on the Oahu Island in November 1998. The bird was admitted for rehabilitation at a local zoological park and died 40 days later. Significant gross lesions included heavy wet lungs that sank in formalin, friable spleen, and engorged cerebral vasculature. Histology revealed marked diffuse necrosis and mononuclear inflammation in the lungs associated with tachyzoites, suppurative periportal inflammation of the liver, severe mononuclear inflammation associated with tachyzoites in the heart, focal neuronal necrosis of the cerebrum associated with bradyzoites, 


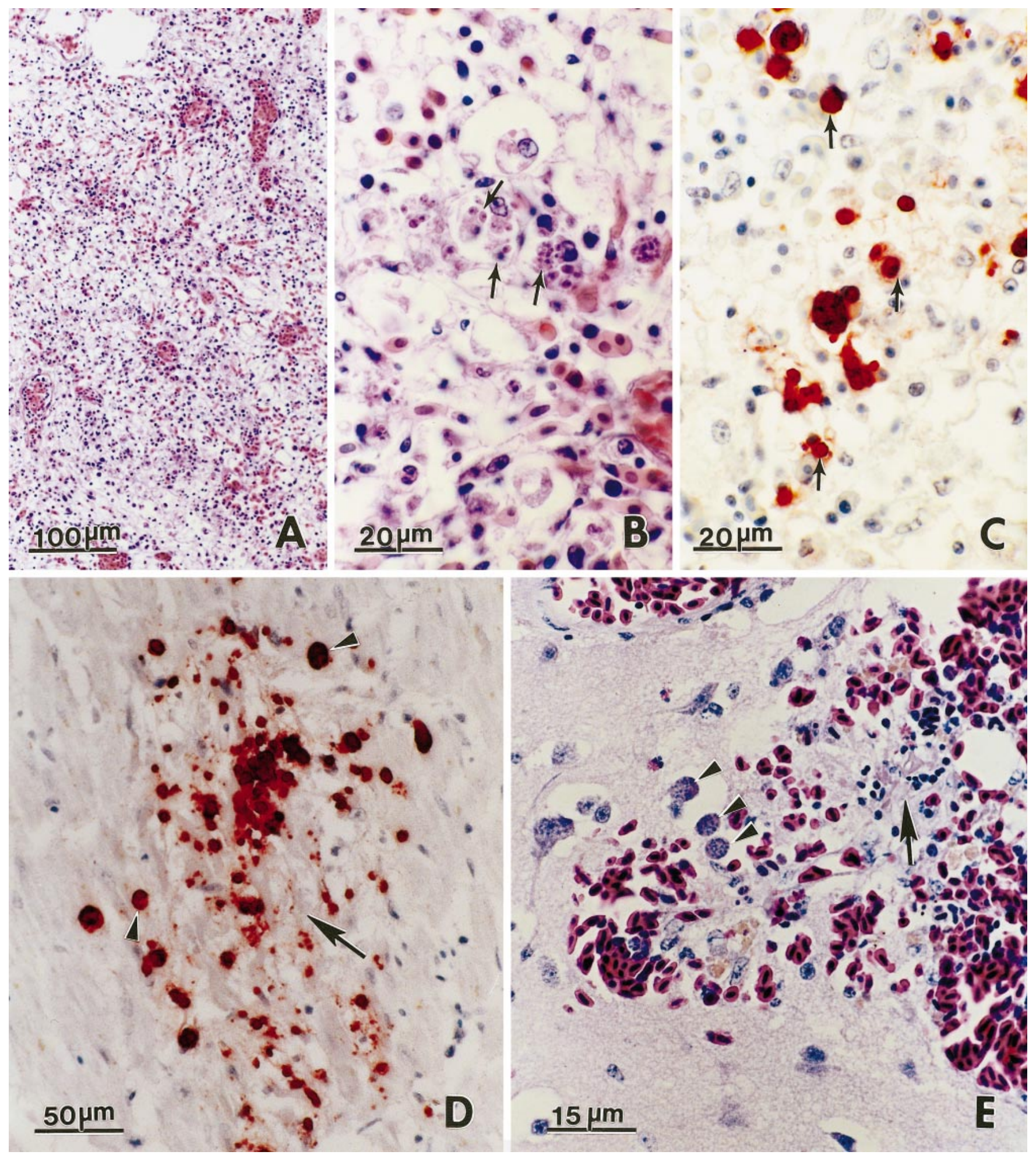

Figure 1. Toxoplasma gondii and associated lesions in birds from Hawaii. A, B, and E, hematoxylin and eosin stain; $\mathbf{C}$ and $\mathbf{D}$, immunohistochemical stain with anti-T. gondii antibodies. (A-C) Lungs of nene goose. Note necrosis, infiltration by mononuclear cells, and individual tachyzoites (arrows) and groups of tachyzoites. Tachyzoites in B appear half the size of those in C. (D) Necrosis of myocardium of Erckel's francolin. Numerous tachyzoites (arrows) are in the lesion. (E) Cerebrum of red-footed booby. Note perivasculitis (arrow) and 3 tissue cysts (arrowheads). 
prominent mononuclear cell hyperplasia in the spleen, and focal necrosis and nonsuppurative inflammation in the adrenal (Fig. 1E). Tissue cysts positive for BAG-1 were seen in intestines, lung, brain, and heart

Protozoans in all 4 birds reacted to anti-T. gondii but not to anti- $S$. neurona polyclonal antibodies.

The nene acquired infection in captivity, and it is likely that their environment (sand substrate) was conducive to the spread of toxoplasmosis by ingested feces from feral cats that were commonly observed in the vicinity. The source of infection for the francolin and the booby is less clear. The francolin may have acquired $T$. gondii through ingestion of oocysts from cat feces or a transport host (Wallace, 1973). We suspect that the booby acquired infection in the wild and not in captivity. Birds undergoing rehabilitation at the zoological park are caged and housed on concrete, which is cleaned daily, thus minimizing potentia exposure to cat feces. On the other hand, feral cats are common around the largest red-footed booby colony on Oahu at the Kaneohe Marine Corps Air Station, and we suspect that the bird acquired the infection there.

Lesions in these birds were similar to those of other avian species infected with T. gondii (Dubey, 2002). The presence of tachyzoites in multiple organs suggested that the disease was more fulminant in the geese and francolin, and the presence of ingesta in the proventriculus of the latter suggested acute death. Presence of bradyzoites in the brain of the booby suggested a more chronic infection. In all cases, the heart and lung were the organs most commonly and severely affected.

In addition to Hawaii (Work et al., 2000), this article extends the geographic range of avian toxoplasmosis to 3 more islands (Maui, Kauai, and Oahu). Feral cats are present on all these islands, thereby providing opportunities for infection of avian hosts. This article also reinforces the fact that $T$. gondii is capable of infecting a wide variety of birds with disparate life histories, including upland game birds (Francolin), pelagic seabirds (Booby), and low-elevation-grazing anseriforms (nene geese). The fact that so few birds of these species have been documented with $T$. gondii suggests that these cases were accidental infections. To date, we have no evidence that $T$. gondii poses a severe threat to populations of these birds.

\section{LITERATURE CITED}

Dubey, J. P. 2002. A review of toxoplasmosis in wild birds. Veterinary Parasitology 106: 121-153.

, AND C. P. BeAtTiE. 1988. Toxoplasmosis of animals and man. CRC Press, Boca Raton, Florida, 220 p.

, AND A. N. HAMIR. 2000. Immunohistochemical confirmation of Sarcocystis neurona infections in raccoons, mink, cat, skunk, and pony. Journal of Parasitology 86: 1150-1152.

LiNDSAY, D. S., AND J. P. DuBEY. 1989. Immunohistochemical diagnosis of Neospora caninum in tissue sections. American Journal of Veterinary Research 50: 1981-1983.

Literák, I., K. HejličeK, J. Nezval, and C. Folk. 1992. Incidence of Toxoplasma gondii in a population of wild birds in the Czech republic. Avian Pathology 21: 659-665.

McAllister, M. M., S. F. Parmley, L. M. Weiss, V. J. Welch, And A. M. MCGUIRE. 1996. An immunohistochemical method for detecting bradyzoite antigen (BAG 5) in Toxoplasma gondii-infected tissues cross-reacts with a Neospora caninum bradyzoite antigen. Journal of Parasitology 82: 354-355.

Wallace, G. D. 1973. Intermediate and transport hosts in the natural history of Toxoplasma gondii. American Journal of Tropical Medicine and Hygiene 22: 456-464.

, L. Marshall, and M. Marshall. 1972. Cats, rats and toxoplasmosis on a small Pacific island. American Journal of Epidemiology 95: 475-482.

Work, T. M., J. G. Massey, B. A. Rideout, C. H. Gardiner, D. B Ledig, O. C. H. KwoK, AND J. P. Dubey. 2000. Fatal toxoplasmosis in free-ranging endangered 'Alala from Hawaii. Journal of Wildlife Diseases 36: 205-212. 